Materiales de Construcción

Vol. 59, 293, 21-34

enero-marzo 2009

ISSN: 0465-2746

eISSN: $1988-3226$

doi: $10.3989 / \mathrm{mc} .2009 .42407$

\title{
Hidratación del cemento de aluminato de calcio en condiciones de muy elevada alcalinidad
}

\section{Calcium aluminate cement hydration in a high alkalinity environment}

\author{
C. Pastor $(*)$, A. Fernández-Jiménez $(*)$, T. Vázquez ${ }^{(*)}$ y $\underline{\text { Á. Palomo }}^{(*)}$
}

Recepción/Received: 4-VI-07

Aceptación/Accepted: 23-X-07

Publicado online/Online publishing: 23-II-09

\section{RESUMEN}

El presente trabajo forma parte de una amplia investigación cuyo objetivo principal es el de elaborar nuevos materiales con propiedades cementantes mediante la activación alcalina de materiales de naturaleza silito-aluminosa. En estos estudios se contempla la posibilidad de utilizar pequeños porcentajes de cemento de aluminato de calcio (CAC) como fuente de aluminio reactivo. Por ello inicialmente se ha estudiado el comportamiento de los CAC en medios fuertemente alcalinos (disoluciones de $\mathrm{NaOH} 2 \mathrm{M}, 8 \mathrm{M}$ y $12 \mathrm{M}$ ). Se determinaron las resistencias mecánicas a 2, 28 y 180 días y se realizó una caracterización de los productos de reacción formados por DRX, FIIR. Como sistema de referencia se consideró la hidratación del CAC con agua.

Los resultados obtenidos muestran que en medios fuertemente alcalinos se retrasan los procesos de rápido endurecimiento de CAC con agua. No obstante a 28 días se obtienen valores de resistencia a compresión $\geq 80 \mathrm{MPa}$. Como principales productos de reacción, a temperatura ambiente y desde los dos días de curado, se forman el aluminato cúbico $\mathrm{C}_{3} \mathrm{AH}_{6}$ y el $\mathrm{AH}_{3}$ en distintas formas polimórficas, en vez de los aluminatos hexagonales $\left(\mathrm{CAH}_{10}\right.$ y $\mathrm{C}_{2} \mathrm{AH}_{8}$ ) que se forman en la hidratación normal con agua.

Palabras clave: activación alcalina, cemento de aluminato de calcio (CAC), DRX, FTIR.

\section{SUMMARY}

The present paper forms part of a broader research project that aims primarily to devise new cementitious products via the alkali activation of silico-aluminous materials. This work addresses the possibility of using small percentages of calcium aluminate cement (CAC) as a source of reactive aluminium. For this reason, a preliminary review was needed of the behaviour of CACs in highly alkaline media $(2,8$ and $12 \mathrm{M} \mathrm{NaOH}$ solutions). Two, 28- and 180-day mechanical strength was determined and the reaction products were characterized with XRD and FTIR. The water-hydrated CAC was used as the control.

The results obtained showed that CAC hardening took place much more slowly in highly alkaline media than in water. Nonetheless, the 28-day compressive strength obtained, $\geq 80 \mathrm{MPa}$. As main reaction products, to ambient temperature and from the two days of cured, cubic aluminate $\mathrm{C}_{3} \mathrm{AH}_{6}$ ), and $\mathrm{AH}_{3}$ polymorphs are formed, instead of the usual hexagonal aluminatos $\left(\mathrm{CAH}_{10}\right.$ and $\mathrm{C}_{2} \mathrm{AH}_{8}$ ) that are formed in the normal hydrate with water.

Keywords: alkali activation, calcium aluminate cement $(C A C), X R D, F T I R$.

(*) Instituto de Ciencias de la Construcción Eduardo Torroja (CSIC), Madrid, España 


\section{INTRODUCCIÓN}

El cemento Portland presenta actualmente diversos problemas, como son el alto grado de contaminantes que se emite a la atmósfera en su fabricación (gases que provocan el efecto invernadero, especialmente $\mathrm{CO}_{2}$ y $\mathrm{NO}_{\mathrm{x}}$ ) (1), y algunas limitaciones tecnológicas, relacionadas con la durabilidad de los hormigones (2).

De ahí la importancia del desarrollo de nuevos materiales cementantes que permitan reemplazar en determinadas aplicaciones al cemento Portland, sin perder en prestaciones pero mejorando el impacto medioambiental. En este sentido, se están realizando investigaciones científicas y técnicas dirigidas hacia el desarrollo de nuevos conglomerantes activados alcalinamente (3-8). Una característica esencial de estos nuevos materiales es la de poder utilizar las cenizas volantes como conglomerante mayoritario, junto con pequeñas proporciones de otros materiales $(4,7,8)$. Estudios previos han mostrado que el principal producto de reacción de la activación alcalina de las cenizas volantes procedentes de las centrales termoeléctricas es un gel de aluminosilicato sódico (5-7). La razón por la que se propone la incorporación de cemento de aluminato de calcio (CAC) al proceso de elaboración de hormigones alcalinos es que muchos materiales potencialmente susceptibles de ser activados alcalinamente carecen de aluminio suficiente en sus composiciones para generar un producto con suficientes prestaciones mecánicas, por lo que sería necesario añadírselo para así poder conformar el esqueleto prezeolítico que confiere dichas resistencias mecánicas a los cementos alcalinos.

Por tanto, antes de acometer la activación alcalina de mezclas de materiales susceptibles de ser activados alcalinamente (con bajos contenidos de alúmina reactiva) con cemento de aluminato de calcio, se ha considerado importante llevar a cabo algunos ensayos de hidratación alcalina del CAC, con vistas a determinar su comportamiento en medios fuertemente alcalinos, evaluar el tipo de productos que se forman, sus resistencias mecánicas y su estabilidad.

El CAC es un material en principio muy adecuado para elaborar hormigones de rápido endurecimiento ya que su desarrollo de resistencias es muy rápido. Los procesos de hidratación del cemento de aluminato de calcio han sido ampliamente estudiados por distintos autores (9-17). Inicialmente, en la normal hidratación del cemento de aluminato de calcio con agua a temperatura ambiente se forman los aluminatos cálcicos hidratados hexagonales ${ }^{1}$ $\mathrm{CAH}_{10}$ y $\mathrm{C}_{2} \mathrm{AH}_{8}$ (la proporción de uno u otro hidratado está condicionada principalmente por la temperatura de

1 En química del cemento los compuestos se expresan como suma de óxidos: $\mathrm{C}=\mathrm{CaO} ; \mathrm{A}=\mathrm{Al}_{2} \mathrm{O}_{3} ; \mathrm{H}=\mathrm{H}_{2} \mathrm{O} ; \mathrm{S}=\mathrm{SiO}_{2}$

\section{INTRODUCTION}

Today the use and production of Portland cement face a number of problems, including the highly polluting emissions (greenhouse gases, especially $\mathrm{CO}_{2}$ and $\mathrm{NO}_{x}$ ) generated during its manufacture (1) and certain technological limitations relating to concrete durability (2).

Hence the importance of developing new cementitious materials to replace Portland cement in certain applications, with a view to reducing its environmental impact without forfeiting performance levels. In this regard, scientific and technical research is underway in pursuit of new alkali-activated binders (3-8). One essential characteristic of these new materials is the ability to use fly ash as a majority binder in conjunction with small proportions of other materials $(4,7,8)$. Earlier studies (5-7) have shown that the main reaction product of the alkali activation of the fly ash from steam power stations is a sodium aluminosilicate gel. The reason for proposing the inclusion of calcium aluminate cement (CAC) in alkaline concrete manufacture is that many alkaline materials potentially susceptible to being alkali-activated lack sufficient aluminium in their composition to generate a product with the necessary strength. Such materials would require additional aluminium to establish the pre-zeolitic skeleton that affords alkaline cements their mechanical properties.

Consequently, before undertaking the alkali activation of materials (with low reactive alumina contents) with calcium aluminate cement, a number of tests were deemed necessary to study CAC behaviour in highly alkaline media and determine the types of products formed, along with their mechanical strength and stability.

CAC is, in principle, a very well-suited material for designing rapid hardening concrete, for it develops strength very quickly. Calcium aluminate cement hydration has been studied in depth by a number of authors (9-17). In standard water hydration of calcium aluminate cement at ambient temperature, the calcium aluminates initially formed are hexagonal1: $\mathrm{CAH}_{10}$ and $\mathrm{C}_{2} \mathrm{AH}_{8}$ (the proportion of one or the other depending primarily on hydration temperature). These hexagonal aluminates are metastable, evolving with time into cubic aluminate

1 In cement chemistry compounds are expressed as the sum of oxides: $\mathrm{C}=\mathrm{CaO} ; \mathrm{A}=\mathrm{Al}_{2} \mathrm{O}_{3} ; \mathrm{H}=\mathrm{H}_{2} \mathrm{O} ; \mathrm{S}=\mathrm{SiO}_{2}$ 
hidratación). Dichos aluminatos hexagonales son metaestables, evolucionando con el tiempo al aluminato cúbico $\left(\mathrm{C}_{3} \mathrm{AH}_{6}\right)$, y formando en esa reacción $\mathrm{AH}_{3}$ y agua. El $\mathrm{C}_{3} \mathrm{AH}_{6}$ es el único aluminato cálcico hidratado estable a temperatura ambiente. Con la conversión $\mathrm{CAH}_{10} \rightarrow \mathrm{C}_{3} \mathrm{AH}_{6}$ se produce una caída de las resistencias mecánicas, debido, entre otras razones, a que el aluminato cúbico es más denso que los aluminatos hexagonales, lo que provoca un aumento de la porosidad del material (18).

Por otra parte, en estudios previos se ha observado que la activación alcalina acelera el proceso de conversión, produciendo aluminato en forma cúbica desde las primeras edades (19-21). Sin embargo los estudios realizados hasta la fecha sobre la hidratación alcalina del CAC se han mantenido en niveles moderados de alcalinidad (1921), por lo que hasta el momento de publicar los resultados de esta investigación no había datos ni información del comportamiento del CAC en medios fuertemente alcalinos (de elevada concentración de álcalis).

El objetivo de esta investigación es someter al CAC a hidrataciones alcalinas, abarcando las disoluciones de hidratación todo un rango de concentraciones de $\mathrm{NaOH}$ (desde 0 hasta $12 \mathrm{M}$ ) para observar las propiedades y características que presenta el cemento de aluminato de calcio activado, así como su evolución en función de la concentración de $\mathrm{NaOH}$ a temperatura ambiente. Como sistema de referencia se usa el CAC hidratado con agua. Además, también, se estudió la evolución en el tiempo $(2,28$ y 180 días $)$ de las fases formadas.

\section{PARTE EXPERIMENTAL}

En el presente trabajo se empleó un cemento de aluminato de calcio (CAC) cuya composición se detalla en la Tabla 1.
$\left(\mathrm{C}_{3} \mathrm{AH}_{6}\right), \mathrm{AH}_{3}$ and water. At ambient temperature, the only stable hydrated calcium aluminate is $C_{3} A H_{6}$. The conversion of $\mathrm{CAH}_{10} \rightarrow \mathrm{C}_{3} \mathrm{AH}_{6}$ entails a decline in mechanical strength due, among others, to the fact that cubic aluminate is denser than the hexagonal varieties, which ultimately leads to a more porous material (18).

Furthermore, previous studies found that alkali activation accelerated this conversion, yielding cubic aluminate from the very earliest ages (19-21). Nonetheless, since to date the studies on the alkali hydration of CAC have been conducted at moderate alkaline levels (1921), at this writing no data on the behaviour of CAC in highly alkaline media (with a high alkali concentration) have yet been forthcoming.

This study aimed to hydrate CAC in alkaline solutions covering a wide range of $\mathrm{NaOH}$ concentrations (from 0 to $12 \mathrm{M}$ ) to observe the properties and characteristics of activated calcium aluminate cement and its behaviour at ambient temperature under such conditions. The control used was water-hydrated CAC. The phases formed over time (2, 28 and 180 days) were also studied.

\section{EXPERIMENTAL PART}

The composition of the calcium aluminate cement (CAC) used in this study is given in Table 1.

Tabla 1 / Table 1

Análisis químico del cemento aluminoso original (\% en peso).

Chemical analysis of original aluminous cement (\% wt).

\begin{tabular}{|c|c|c|c|c|c|c|c|c|c|}
\hline $\mathbf{S i O}_{\mathbf{2}}$ & $\mathbf{A l}_{\mathbf{2}} \mathbf{O}_{\mathbf{3}}$ & $\mathbf{F e}_{\mathbf{2}} \mathbf{O}_{\mathbf{3}}$ & $\mathbf{M g O}$ & $\mathbf{C a O}$ & $\mathbf{N a}_{\mathbf{2}} \mathbf{O}$ & $\mathbf{T i O}_{\mathbf{2}}$ & $\mathbf{M n O}$ & Otros & Total \\
\hline 3.72 & 44.91 & 15.00 & 0.80 & 33.53 & 0.18 & 1.46 & 0.02 & 0.38 & 100 \\
\hline
\end{tabular}

Se prepararon pastas de CAC con agua (sistema de referencia) y con diferentes disoluciones de hidróxido sódico $(2$, 8 y $12 \mathrm{M}$ ) (ver Tabla 2). Las disoluciones alcalinas se prepararon con $\mathrm{NaOH}$ en forma de lentejas Panreac S. A. - ACSISO de pureza del $98 \%$. En la elaboración de las pastas cementantes se emplearon diferentes relaciones "líquido/sólido" para obtener consistencias similares, tal y como se muestra en la Tabla 2 . Con dichas pastas se prepararon probetas prismáticas de $1 \times 1 \times 6 \mathrm{~cm}$, realizándose
CAC pastes were prepared with water (control system) and 2, 8, and $12 \mathrm{M}$ sodium hydroxide solutions (Table 2). The alkaline solutions were prepared with ACS-ISO 98\% $\mathrm{NaOH}$ pellets supplied by Panreac S.A. Different liquid/solid ratios were used to obtain cementitious pastes with similar consistencies, as shown in Table 2. Prismatic specimens measuring $1 \times 1 \times 6 \mathrm{~cm} \mathrm{~cm}$ were prepared and cured in a chamber ( $99 \%$ relative humidity, $\left.22{ }^{\circ} \mathrm{C}\right)$. After 
Tabla 2 / Table 2

Datos sobre las condiciones de hidratación del CAC. CAC hydration conditions.

\begin{tabular}{|c|c|c|}
\hline $\begin{array}{c}\text { Denominación del material / } \\
\text { Sample denomination of material }\end{array}$ & $\begin{array}{c}\text { Líquido de hidratación / } \\
\text { Hydrating liquid }\end{array}$ & Relación I/s / L/s ratio \\
\hline CAH & Agua / water & 0,28 \\
\hline CAN2 & $2-\mathrm{M} \mathrm{NaOH}$ & 0,4 \\
\hline CAN8 & $8-\mathrm{M} \mathrm{NaOH}$ & 0,3 \\
\hline CAN12 & $12-\mathrm{M} \mathrm{NaOH}$ & 0,3 \\
\hline
\end{tabular}

su curado en cámara ( $99 \%$ de humedad relativa y $22^{\circ} \mathrm{C}$ de temperatura). Tras 24 horas de curado inicial, se procedió al desmoldeo de las probetas, que se volvieron a guardar en la cámara hasta la edad de ensayo (2, 28 y 180 días).

Para la determinación de las resistencias mecánicas se utilizó el equipo descrito por la norma "UNE-EN 196-1:1996" de carga concentrada y centrada. Tras el control mecánico de las probetas, se procedió a la molienda y posterior "congelación" de los materiales (con acetona y etanol) para evitar el avance de las reacciones. Finalmente los materiales se caracterizaron mineralógica y microestructuralmente mediante DRX y FTIR.

La difracción de rayos $X$ de las muestras se realizó con un equipo Phillips modelo PW-1700 que consta de un generador de alta tensión de $4 \mathrm{KW}$, tubo de rayos $\mathrm{X}$ con ánodo de cobre que trabaja normalmente a $40 \mathrm{KV}$ y $50 \mathrm{~mA}$, rendija automática de divergencia, monocromador de grafito y cambiador automático de muestras. La espectroscopía infrarroja (FTIR) se llevó a cabo mediante un espectrómetro ATIMATTSON GENESIS. Las muestras fueron preparadas mezclando $1 \mathrm{mg}$ de muestra con $300 \mathrm{mg}$ de $\mathrm{KBr}$. Los barridos se efectuaron en la región del infrarrojo medio, es decir, a una frecuencia de $4000 \mathrm{~cm}^{-1}$ a $400 \mathrm{~cm}^{-1}$, con una resolución espectral de $4 \mathrm{~cm}^{-1}$.

\section{RESULTADOS}

\subsection{Caracterización mecánica}

En la Tabla 3 se presentan los valores de resistencia mecánica tanto a flexión como a compresión de los diferentes materiales estudiados. Estos resultados indican que el cemento hidratado con agua, tal y como era de esperar, desarrolla desde primeras edades unas resistencias mecánicas a compresión muy elevadas. Sin embargo, esta resistencia no sigue aumentando con la edad de curado. A 28 días se obtienen valores similares a los de 2 días, mientras que a 180 días estos valores incluso disminuyen ligeramente.

En cuanto a las muestras hidratadas en condiciones alcalinas, la resistencia a compresión a 2 días de todas ellas es muy inferior a la de la muestra de referencia, situándose en
24 hours of initial curing, the specimens were demoulded and returned to the chamber, where they were stored until they reached the test age $(2,28$ or 180 days).

Mechanical strength was determined with the concentrated load test apparatus described in Spanish and European standard UNE-EN 196-1:1996. After the specimens were tested for strength, they were ground and subsequently frozen (in acetone and ethanol) to prevent the reactions from progressing any farther. Finally, the mineralogy and microstructure of the materials were characterized with XRD and FTIR.

The samples were examined with a Philips PW-1700 Xray diffractometer, consisting of a high voltage, 4-kW generator and a copper anode $X$-ray tube and fitted with an automatic divergence slit, graphite monochromator and automatic sample changer. Standard operating conditions were $40 \mathrm{kV}$ and $50 \mathrm{~mA}$. Infrared spectroscopy (FTIR) was conducted on an ATIMATTSON GENESIS spectrometer. The samples were prepared by mixing $1 \mathrm{mg}$ of sample with $300 \mathrm{mg}$ of $\mathrm{KBr}$. The scans were taken in the mid-infrared region, i.e., at frequencies of $4000 \mathrm{~cm}^{-1}$ to $400 \mathrm{~cm}^{-1}$, with a spectral resolution of $4 \mathrm{~cm}^{-1}$.

\section{RESULTS}

\subsection{Strength}

Table 3 gives the bending and compressive strength values for the materials studied. These results indicate that, as expected, the water-hydrated cement developed very high bending and compressive strength at early ages. Nonetheless, strength did not grow with curing age. The 28-day values were similar to the 2-day findings, while after 180 days these values actually declined slightly.

In the samples hydrated under alkaline conditions, the 2day compressive strength was much lower than found for the control, with a value of around $10 \mathrm{MPa}$. These values 
Tabla 3 / Table 3

Resistencias mecánicas a compresión y flexión de las probetas a 2,28 y 180 días. CAC specimens: 2-, 28- and 180-day compressive and bending strength.

\begin{tabular}{|c|c|c|c|c|c|c|}
\hline \multicolumn{4}{|c|}{ Resistencias flexión / Bending strength (MPa) } & \multicolumn{3}{c|}{$\begin{array}{c}\text { Resistencias compresión / } \\
\text { Compressive strength (MPa) }\end{array}$} \\
\hline Muestra / Sample & 2 días / 2-day & 28 días / 28-day & $\mathbf{1 8 0}$ días / 180-day & 2 días / 2-day & 28 días / 28-day & $\mathbf{1 8 0}$ días / 180-day \\
\hline CAH & $6.06 \pm 0.89$ & $7,14 \pm 0.60$ & $9.22 \pm 1.73$ & $92.67 \pm 6.63$ & $92,62 \pm 6.47$ & $89.91 \pm 14.90$ \\
\hline CAN2 & $2.93 \pm 0.37$ & $7,07 \pm 0.79$ & $10.92 \pm 1.72$ & $10.24 \pm 0.45$ & $20,49 \pm 1.69$ & $53.02 \pm 2.69$ \\
\hline CAN8 & $3.62 \pm 0.88$ & $10.26 \pm 0.79$ & $17.97 \pm 3.69$ & $10.22 \pm 1.74$ & $80,64 \pm 5.87$ & + de $100(*)$ \\
\hline CAN12 & $0(* *)$ & $6,99 \pm 1.64$ & $15.96 \pm 4.85$ & $0(* *)$ & $34,74 \pm 7.27$ & $74.42 \pm 15.64$ \\
\hline
\end{tabular}

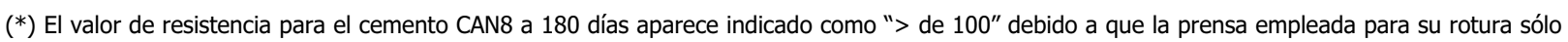
llega hasta $100 \mathrm{MPa}$, lo cual no era suficiente para romper las probetas de esta muestra. / The strength value for 180-day CAN8 cement is shown as "> 100" because the maximum load attainable with the test frame used was $100 \mathrm{MPa}$, under which these specimens did not fail.

$\left.{ }^{* *}\right)$ Los valores de CAN12 a 2 días aparecen como OMPa ya que las probetas no habían endurecido a dicha edad. / The 2-day CAN12 values are shown as $0 \mathrm{MPa}$ because they had not yet hardened at that age.

valores próximos a $10 \mathrm{MPa}$. Sin embargo, estos valores crecen con el tiempo de curado, especialmente con disoluciones muy concentradas en álcalis. Así, mientras que a los 28 días el material CAN2 duplica su resistencia a la compresión, la muestra de cemento hidratada con la disolución de $\mathrm{NaOH}$ $8 \mathrm{M}$ (CAN8), alcanza un valor de $80 \mathrm{MPa}$. Este valor está bastante cercano al valor de referencia alcanzado por el cemento hidratado con agua. En general, la tendencia al alza de las resistencias mecánicas continúa hasta la edad de 180 días, superando la muestra CAN8 los 100 MPa y por tanto, la resistencia obtenida al hidratar el CAC con agua.

Otro hecho importante a destacar es la influencia de la concentración de álcalis. Los resultados de la Tabla 3 muestran que el aumento de la resistencia tiene lugar hasta que la concentración de álcalis alcanza un valor alrededor de 8M, por encima del cual si se sigue aumentando la concentración de la disolución de $\mathrm{NaOH}$, el desarrollo resistente desciende.

En lo que respecta a la resistencia a la flexión, también el CAC activado con $\mathrm{NaOH} 8 \mathrm{M}$ es el que da lugar a las resistencias más altas. A la edad de 180 días, la muestra CAN8 presenta un valor muy elevado de resistencias mecánicas a flexión ( $\approx 18 \mathrm{Mpa}$ ); valor que dobla el obtenido a 28 días.

\subsection{Caracterización mineralógica y microestructural}

En la Figura 1(a) se presentan los difractogramas de las muestras tras 2 días de hidratación. En el correspondiente a la muestra hidratada con agua, se observa la presencia de los picos característicos del $\mathrm{CAH}_{10}$. En los de las muestras hidratadas alcalinamente aparecen los picos del $\mathrm{AH}_{3} \mathrm{y}$ del $\mathrm{C}_{3} \mathrm{AH}_{6}$; se observa que la intensidad de los picos debidos a este último compuesto es superior en los difractogramas de la muestra hidratada con mayor concentración de $\mathrm{NaOH}(8 \mathrm{M})$. Además se comprueba que en esas muestras, el $\mathrm{AH}_{3}$ existe como mezcla de gibsita y bayerita; la proporción de esta última es bastante superior en el CAN8. grew with curing time, however, particularly in the samples hydrated with highly concentrated alkaline solutions. While the CAN2 sample doubled its compressive strength after 28 days, the value recorded for the cement hydrated with an 8-M NaOH solution (CAN8) was $80 \mathrm{MPa}$. This was very close to the strength attained by the waterhydrated cement. Generally speaking, mechanical strength continued to rise through the age of 180 days, with the CAN8 sample exceeding $100 \mathrm{MPa}$ and, therefore, the strength found for the water-hydrated CAC.

Another relevant finding was the effect of alkali concentration. The results in Table 3 show that strength increased with alkali concentration up to a value of around 8M; at higher [NaOH], strength development declined.

The CAC activated with 8-M NaOH, which was likewise the sample exhibiting the highest bending strength, doubled its 28-day value after 180 days, to $\approx 18 \mathrm{MPa}$.

\subsection{Mineralogy and microstructure}

The diffractograms for the 2-day samples are shown in Figure 1(a). Peaks characteristic of $\mathrm{CAH}_{10}$ were observed on the pattern for the water-hydrated sample, while signals attributed to $\mathrm{AH}_{3}$ and $\mathrm{C}_{3} A \mathrm{H}_{6}$ appeared on the traces for the alkali-hydrated samples. Note that the intensity of the $\mathrm{C}_{3} A \mathrm{H}_{6}$ peaks was higher in the diffractogram for sample CAN8, which was hydrated at a higher alkalinity (8M NaOH). $\mathrm{AH}_{3}$ was found to exist as a mixture of gibbsite and bayerite in these samples also, although in different proportions. The latter accounted for a substantially greater fraction in CAN8. 
La Figura 1(b) muestra los difractogramas de los mismos materiales anteriores, pero tras 28 días de reacción. En los de la muestra hidratada en ausencia de álcalis hay picos de baja intensidad que indican la presencia de $\mathrm{CAH}_{10}$ en baja proporción. También se observan los picos correspondientes a $\mathrm{C}_{3} \mathrm{AH}_{6}$ y $\mathrm{AH}_{3}$ (gibsita) aunque con intensidad baja.

Las muestras hidratadas alcalinamente (CAN2, CAN8 y CAN12) a 28 días generan unos difractogramas en los que se observa, como principal diferencia, que según aumenta la alcalinidad de la disolución se produce la evolución progresiva del $\mathrm{AH}_{3}$ (gibsita) hacia la forma bayerita. Además, también se observa, un menor contenido de fases anhidras con respecto a los difractogramas correspondientes a los materiales de 2 días. $\mathrm{A}$ edades superiores, 180 días (ver Figura $1(\mathrm{c})$ ), en los difractogramas de las muestras CAN2, CAN8 y CAN12 llama la atención la disminución de la intensidad de los picos del $\mathrm{C}_{3} \mathrm{AH}_{6}$ y el incremento de la intensidad de los picos asociados a la presencia de bayerita y de carbonatos.

Como aspectos de menor relevancia hay que mencionar que de las muestras a 28 y 180 días se observa que éstas han sufrido una ligera carbonatación, que ha formado $\mathrm{C}_{4} \mathrm{AcH}_{11}$, con especial intensidad en el material CAN2.
Figure 1(b) shows the 28-day diffractograms for the same materials. The peaks on the pattern for the sample hydrated without alkalis were indicative of the presence of low proportions of $\mathrm{CAH}_{10}$. Peaks attributable to $\mathrm{C}_{3} A \mathrm{H}_{6}$ and $\mathrm{AH}_{3}$ (gibbsite) were also observed, although at very low intensity.

The diffractograms recorded for the 28-day alkali-hydrated samples (CAN2, CAN8 and CAN12) revealed the progressive transformation of $\mathrm{AH}_{3}$ (gibbsite) to bayerite with increasing alkalinity. These XRD traces also showed that the anhydrous phase content was lower than in the 2-day samples. The most significant findings in the 180day diffractograms for CAN2, CAN8 and CAN12 (Figure 1(c)) were the declining intensity of the $C_{3} A H_{6}$ peaks and the rising intensity of the peaks associated with bayerite and carbonates.

Other findings of lesser relevance included the slight carbonation observed in the 28- and 180-day samples, with the formation of $\mathrm{C}_{4} \mathrm{AcH}_{11}$, most visibly in sample CAN2. All the samples also had small proportions of
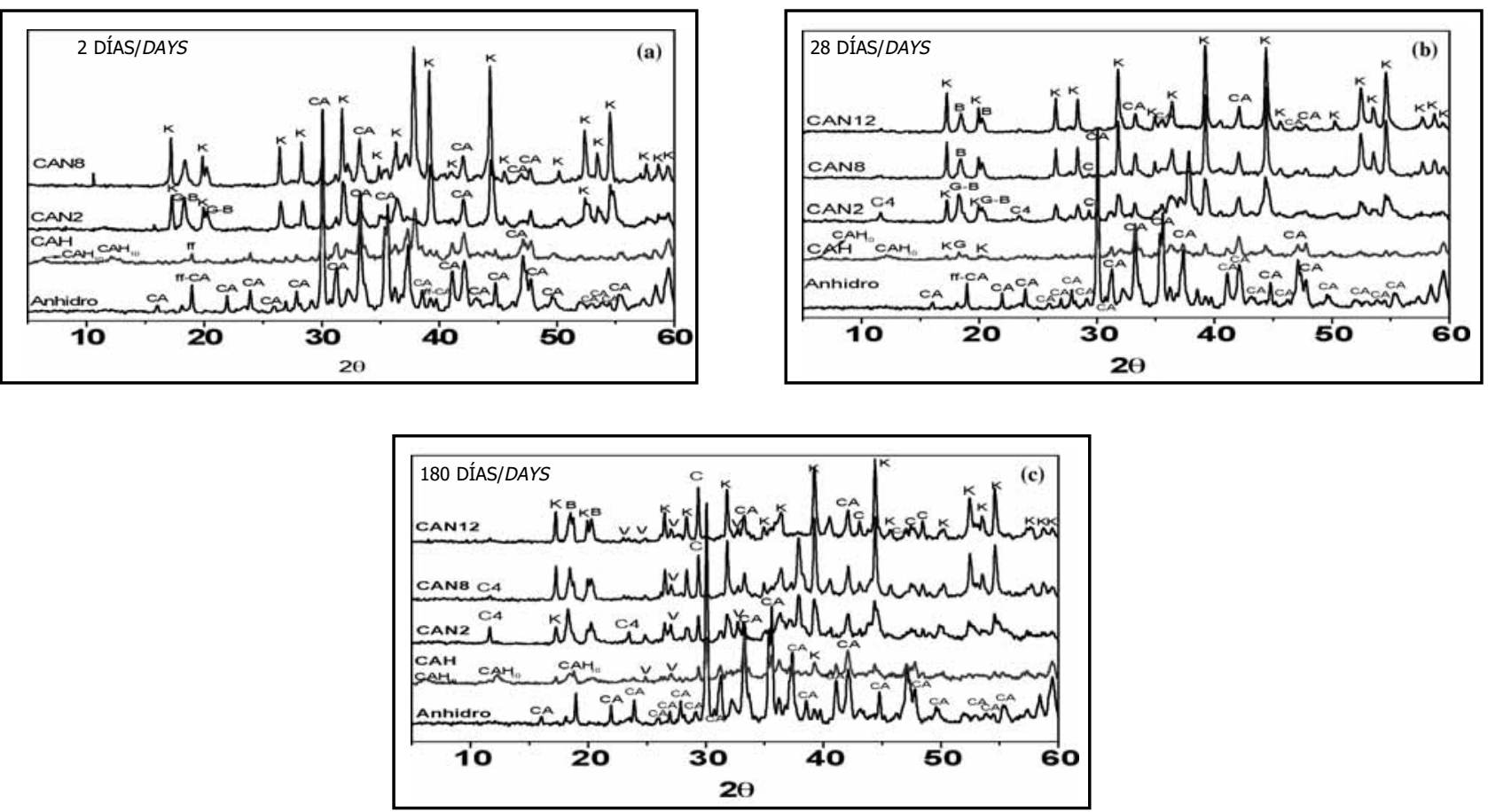

Figura 1. Difractogramas del CAC anhidro e hidratado en diferentes condiciones de alcalinizad : (a) 2 días; (b) 28 días y (c) 180 días. $C A=$ Aluminato monocálcico; $B=$ Bayerita; $K=: K a t o i t a\left(C_{3} A H_{6}\right)$; ff=fase ferrítica ; $C A H_{10}: ; C_{2} A H_{8}:$; G: Gibbsita. $C=$ calcita y $C 4=C_{4} A c H_{11}$.

Figure 1. CAC diffractograms: anhydrous and hydrated CAC under different alkalinity conditions: (a) 2 days; (b) 28 days; (c) 180 days. $C A=$ monocalcium aluminate; $B=$ bayerite; $K=$ katoite $\left(C_{3} A H_{6}\right)$; ff=ferritic phase; $C A H_{10}: ; C_{2} A H_{8}$ : ; G: gibbsite. $C={ }^{2}$ calcite; $C 4=C 4 A C H_{11}$. 
Asimismo, todas las muestras contienen $\mathrm{CaCO}_{3}$ en pequeña proporción, con unas diferencias singulares respecto a su forma cristalográfica. En el estudio a través de FTIR se detallarán estas características.

En las Figuras 2, 3 y 4 se presentan los resultados obtenidos tras estudiar estos mismos materiales por espectroscopía infrarroja a 2, 28 y 180 días, respectivamente. Estos resultados confirman y complementan lo indicado por DRX.

La muestra $\mathrm{CAH}$, hidratada 2 días en ausencia de $\mathrm{NaOH}$, genera un espectro IR prácticamente idéntico al del $\mathrm{CAH}_{10}$, destacando su banda característica -muy fuerte y ancha- en $3500 \mathrm{~cm}^{-1}$, de vibraciones $\mathrm{OH}$ (9).

Los espectros IR de las muestras hidratadas con disoluciones alcalinas (CAN2, CAN8, CAN12) se modifican notablemente respecto al del material hidratado sólo con agua. No hay aluminatos hexagonales, sino cúbico $\left(\mathrm{C}_{3} \mathrm{AH}_{6}\right)$, que presenta una banda aguda de $\mathrm{OH}$ en $3667 \mathrm{~cm}^{-1}$ y de frecuencias de vibración específicas del hidróxido de aluminio $\left(\mathrm{AH}_{3}\right)$ en forma de gibsita en la muestra CAN2, con las bandas de $\mathrm{OH}$ libres y $\mathrm{OH}$ asociados, en 3622 - 3527 y $3457 \mathrm{~cm}^{-1}$ y de bayerita con algo de gibsita en las CAN8 y CAN12 (9-12); la bayerita está en más alta proporción en esta última muestra. Estos espectros ponen de manifiesto que entre 2 y 28 días, aumenta el tiempo de hidratación y aumenta la proporción de $\mathrm{C}_{3} \mathrm{AH}_{6}$.
$\mathrm{CaCO}_{3}$, although with distinctly different crystallographies. These differences were revealed by the FTIR study.

Figures 2, 3 and 4 show the infrared spectra for the 2-, 28- and 180-day materials. These results confirm and supplement the XRD findings.

Sample CAH, hydrated for two days in the absence of $\mathrm{NaOH}$, generated an IR spectrum that was practically identical to the $\mathrm{CAH}_{10}$ spectrum, with its characteristic (intense and wide) $\mathrm{OH}$ vibration band at $3500 \mathrm{~cm}^{-1}$ (9).

The IR spectra for the samples hydrated with alkaline solutions (CAN2, CAN8, CAN12) differed substantially from the control spectrum. Rather than hexagonal aluminates, cubic aluminate $\left(C_{3} A H_{6}\right)$ was present, as revealed by the narrow $\mathrm{OH}$ band at $3667 \mathrm{~cm}^{-1}$. Vibration frequencies specific to aluminium hydroxide $\left(\mathrm{AH}_{3}\right)$ also appeared: as gibbsite in sample CAN2, with free and associated $\mathrm{OH}$ bands at 3622 to $3527 \mathrm{~cm}^{-1}$ and $3457 \mathrm{~cm}^{-1}$; and as bayerite with some gibbsite in CAN8 and CAN12 (9-12). The highest proportion of bayerite was found in CAN12. These spectra show that the proportion of $\mathrm{C}_{3} \mathrm{AH}_{6}$ increased with hydration time, up to 28 days.
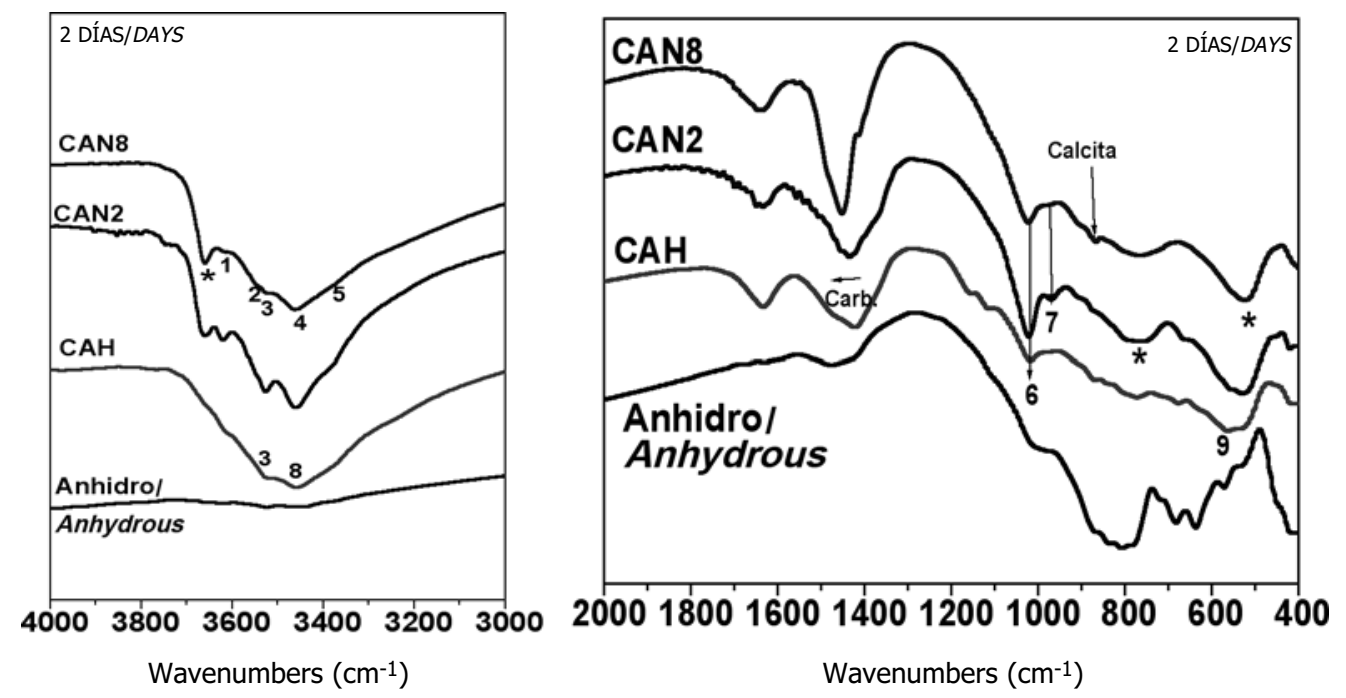

Figura 2. Espectros IR del CAC anhidro e hidratado durante 2 días en diferentes condiciones de alcalinidad. Las bandas correspondientes al $\mathrm{C}_{3} \mathrm{AH}_{6}$ están representadas con el símbolo $\left(^{*}\right)$, mientras que las del $\mathrm{AH}_{3}$ (bayerita) mediante números. La frecuencia a la que corresponde cada número se expone en la Tabla 4.

Figure 2. IR spectra for CAC: anhydrous and hydrated for two days under different alkalinity conditions. The bands attributed to $\mathrm{C}_{3} \mathrm{AH}_{6}$ are labelled (*) and the $\mathrm{AH}_{3}$ (bayerite) bands are numbered. The frequency corresponding to each number is given in Table 4. 

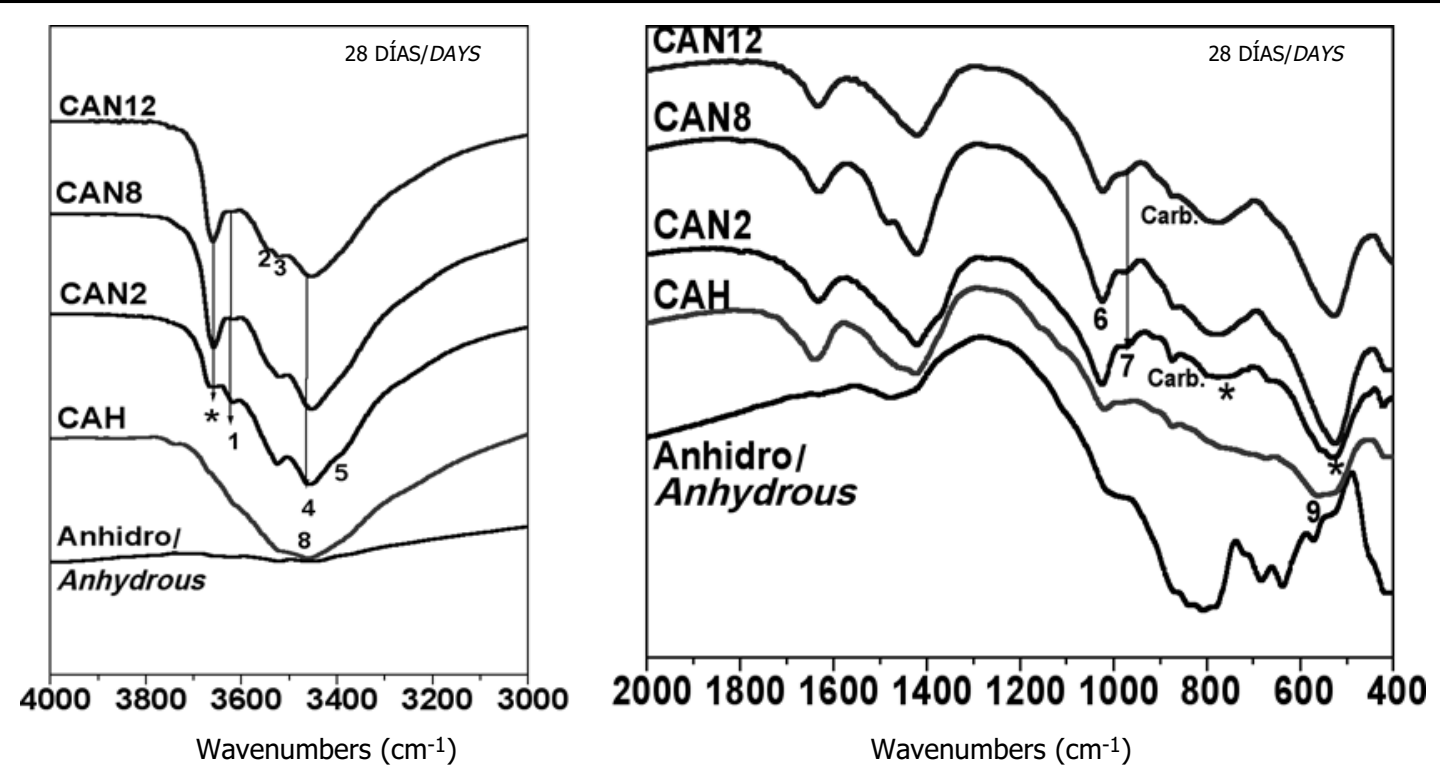

Figura 3. Espectros IR del CAC anhidro e hidratado durante 28 días en diferentes condiciones de alcalinidad. Figure 3. IR spectra for CAC anhydrous and hydrated for 28 days under different alkalinity conditions.

Respecto a las bandas de carbonatos que se observan en los espectros IR, es interesante resaltar que la más característica $\left(v_{4} \mathrm{CO}_{3}\right)$ se desplaza a números de onda más altos, desde $1420 \mathrm{~cm}^{-1}$ en la muestra hidratada con agua hasta $1455 \mathrm{~cm}^{-1}$ en la hidratada con $\mathrm{NaOH} 8 \mathrm{M}$. Probablemente se deba a la presencia de $\mathrm{Na}_{2} \mathrm{CO}_{3}$. Destacar también la presencia de una banda en $1484 \mathrm{~cm}^{-1}$ debida a la vaterita, en la muestra CAN8 tras 28 días de hidratación.
Note that the most characteristic of the carbonate bands on the IR spectra $\left(v_{4} \mathrm{CO}_{3}\right)$, shifted to higher wave numbers, from $1420 \mathrm{~cm}^{-1}$ in the water-hydrated sample to $1455 \mathrm{~cm}^{-1}$ in the sample hydrated with 8-M NaOH. This was probably due to the presence of $\mathrm{Na}_{2} \mathrm{CO}_{3}$. A band at $1484 \mathrm{~cm}^{-1}$, attributed to vaterite, was also visible on the 28-day CAN8 spectrum.
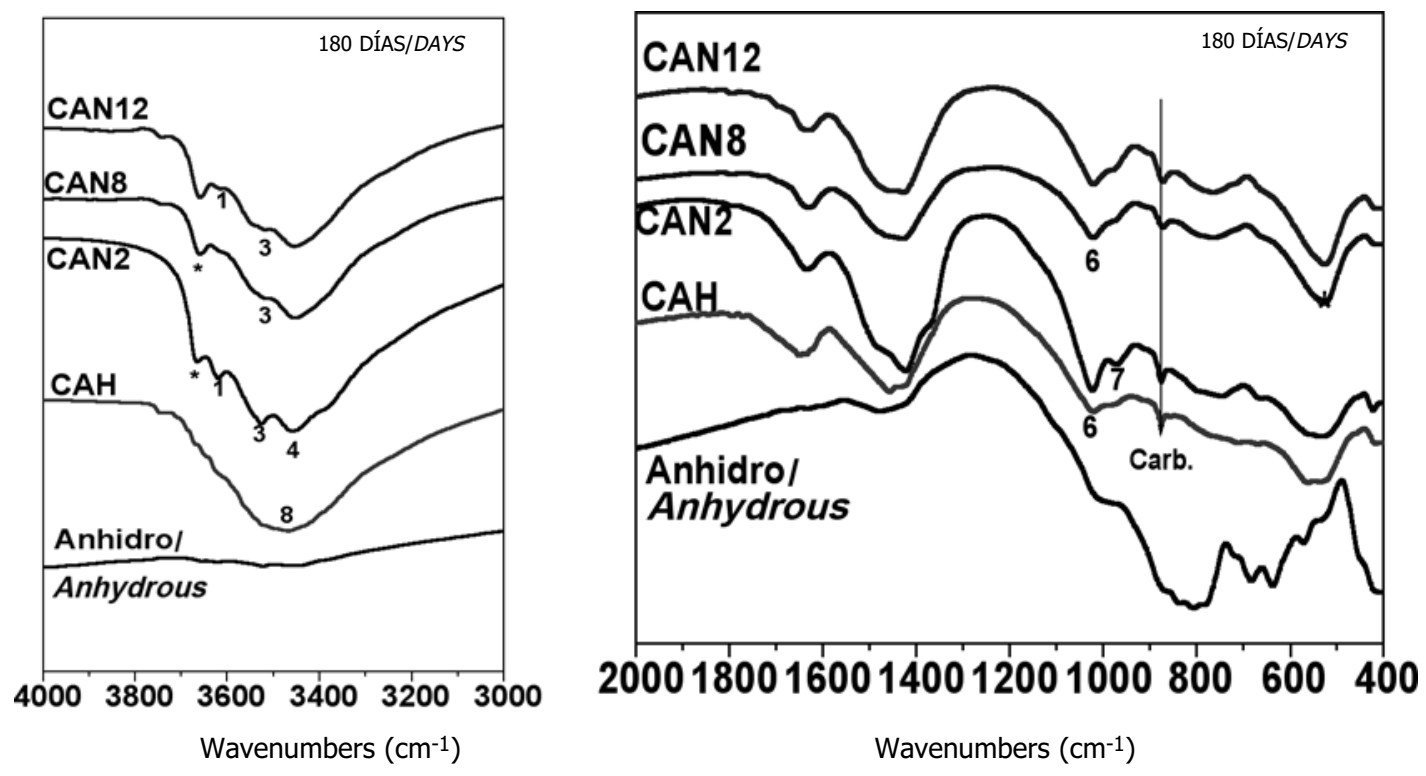

Figura 4. Espectros IR del CAC anhidro e hidratado durante 180 días en diferentes condiciones de alcalinidad.

Figure 4. IR spectra for CAC anhydrous and hydrated for 180 days under different alkalinity conditions. 
En lo que respecta a la interpretación de los espectros IR de las muestras tratadas durante 180 días, los resultados obtenidos confirman lo indicado en el estudio por DRX. Así, se observa que la intensidad de las bandas asignadas a $\mathrm{C}_{3} \mathrm{AH}_{6}$ disminuye mientras que aumenta la proporción de bayerita a medida que aumenta el pH de la disolución.

\section{DISCUSIÓN}

La hidratación del CAC con agua ha sido estudiada ampliamente, existiendo considerables trabajos sobre el sistema $\mathrm{CaO}-\mathrm{Al}_{2} \mathrm{O}_{3}-\mathrm{H}_{2} \mathrm{O}$ a diferentes temperaturas (9, $13,15)$. En nuestro caso, se observa que el cemento CAC utilizado como referencia cumple lo indicado en la bibliografía (9-22). Es decir, a temperatura ambiente $\left(22^{\circ} \mathrm{C}\right)$ y tras 2 días de hidratación se forma el aluminato cálcico hidratado $\mathrm{CAH}_{10}$ junto con trazas de $\mathrm{C}_{2} \mathrm{AH}_{8}$ y $\mathrm{AH}_{3}$, lo cual da lugar a unas muy elevadas resistencias iniciales. A los 28 días la situación es casi idéntica, con un ligero aumento en la presencia de $\mathrm{AH}_{3}$, mientras que a los 180 días ya se detecta la presencia a nivel de trazas de $\mathrm{C}_{3} \mathrm{AH}_{6}$ y una ligera caída de las resistencias.

En las muestras hidratadas con las disoluciones alcalinas hay que destacar tres hechos importantes: i) mayor grado de reacción del CAC; ii) formación del hidrato cúbico en lugar del hexagonal; iii) el $\mathrm{AH}_{3}$ cristaliza preferentemente en forma de bayerita en lugar de gibbsita.

Por lo que respecta al mayor grado de reacción, los resultados de la Figura 1 muestran claramente cómo al aumentar la alcalinidad de la disolución disminuye la intensidad de los picos del CA anhidro. Es decir, la presencia de álcalis en la disolución de amasado tiene un claro efecto acelerador de las reacciones de hidratación de CAC. Ello se asocia a una mayor disolución de las especies anhidras como consecuencia del incremento de las concentraciones de iones $\mathrm{OH}^{-}$en el medio. En medios acuosos a pH neutro, la solubilidad del Ca es muy elevada, sin embargo al aumentar el $\mathrm{pH}$ del medio la velocidad de disolución del calcio disminuye y sin embargo aumenta mucho la del Al (23) formando especies del tipo $\mathrm{Al}(\mathrm{OH})_{4}^{-}$. Una mayor velocidad de solubilización del Al puede justificar que cuando se alcanza el grado de saturación de dicho elemento en la disolución, el Al precipite en forma de $\mathrm{AH}_{3}$. Ello, corrobora la presencia de importantes cantidades de $\mathrm{AH}_{3}$ detectado a 2 días en comparación con el sistema de referencia CAH (ver Figura 1(a) y Figura 2). Además también, podría justificar el hecho de que a pesar del elevado grado de reacción del CAC, en medios fuertemente alcalinos, las resistencias mecánicas iniciales son relativamente bajas, si se comparan con el sistema de referencia (ver Tabla 3). En opinión de los autores de este trabajo, el medio se saturaría en Al para precipitar como $\mathrm{Al}(\mathrm{OH})_{3}$. No obstante resulta obvia la necesidad de hacer más estudios al respecto.
The results of the 180-day IR spectra confirmed the findings of the XRD study. These spectra also showed that the intensity of the bands attributed to $\mathrm{C}_{3} \mathrm{AH}_{6}$ declined, while the proportion of bayerite rose, with the $\mathrm{pH}$ of the hydrating solution.

\section{DISCUSSION}

CAC hydration with water has been widely studied, and a considerable number of authors have been analyzed the $\mathrm{CaO}-\mathrm{Al}_{2} \mathrm{O}_{3}-\mathrm{H}_{2} \mathrm{O}$ system at different temperatures $(9,13,15)$. In the present case, the CAC used as a control was observed to behave as described in the literature (9-22): after two days of hydration at ambient temperature $\left(22{ }^{\circ} \mathrm{C}\right)$, hydrated calcium aluminate $\mathrm{CAH}_{10}$ formed, along with traces of $\mathrm{C}_{2} \mathrm{AH}_{8}$ and $\mathrm{AH}_{3}$, giving rise to very high initial strength values. The situation after 28 days was identical, with a slight increase in $\mathrm{AH}_{3}$, whereas after 180 days traces of $C_{3} A_{1} H_{6}$ were found and a slight decline in strength was recorded.

Three important findings in connection with the samples hydrated with alkaline solutions should be highlighted: i) the CAC exhibited a higher degree of reaction; ii) cubic rather than hexagonal hydrates formed; iii) the $\mathrm{AH}_{3} \mathrm{Crys}$ tallized predominantly as bayerite, not gibbsite.

Figure 1 clearly shows that the intensity of the anhydrous CA peaks declined with rising alkalinity, an indication of a higher degree of reaction. In other words, the presence of alkalis in the mixing solution clearly accelerated CAC hydration reactions. This can be attributed to more effective dissolution of the anhydrous species as a result of the increase in ion $\mathrm{OH}^{-}$ concentration in the medium. In neutral $\mathrm{pH}$ aqueous solutions, Ca solubility is very high. But as $\mathrm{pH}$ rises the dissolution rate of $\mathrm{Ca}$ declines while the $A$ l rate climbs (23), leading to the formation of $A L(O H)_{4}^{-}$type species. A higher $A$ l solubilization rate may explain the precipitation of $\mathrm{AH}_{3}$ in Al-saturated solutions. This would corroborate the presence of much larger amounts of $\mathrm{AH}_{3}$ in the alkaline-hydrated than in the $\mathrm{CAH}$ control samples after two days of hydration (see Figures 1(a) and 2). It may also explain why, despite the high degree of reaction in the CAC hydrated in highly alkaline media, the initial strength values were lower than in the control (see Table 3). While the medium might plausibly be thought to have become Al-saturated, with the element precipitating as $\left(\mathrm{Al}(\mathrm{OH})_{3}\right.$, further research is obviously needed in this regard. 
Al aumentar el tiempo de curado va aumentando la cantidad de calcio que reacciona, formándose una mayor cantidad de $\mathrm{C}_{3} \mathrm{AH}_{6}$ (Ver Fig. 1(a), (b) y (c)) y probablemente con una mayor cristalinidad. Ello justificaría que a los 28 días de curado, los cementos hidratados alcalinamente aumenten considerablemente su resistencia mecánica (tanto a flexión como a compresión), llegando a los $80 \mathrm{MPa}$ a compresión el cemento CAN8.

En lo que respecta a los productos de reacción formados, diferentes autores $(16-19,21)$ señalan el hecho de que la presencia de pequeñas concentraciones de álcalis en el líquido de amasado acelera el proceso de conversión de los hidratos hexagonales a cúbicos. En nuestro caso, debido a las condiciones de tan elevada alcalinidad (8M y $12 \mathrm{M})$, los aluminatos hexagonales metaestables ya han sufrido la conversión a cúbico tras dos días de hidratación, proceso que puede tardar años en desarrollarse al hidratar el CAC con agua.

Otra de las principales diferencias observadas entre hidratar el CAC con agua o con disoluciones alcalinas es la forma polimórfica que presenta el $\mathrm{AH}_{3}$. Con agua (CAH) el $\mathrm{AH}_{3}$ cristaliza en forma de gibbsita. En condiciones de alcalinidad suaves, CAN2, también cristaliza en forma de gibbsita, o, en todo caso, como mezcla de gibbsita y bayerita, siendo la gibbsita la forma predominante. Sin embargo en medios fuertemente alcalinos, CAN8 y CAN12, la forma predominante es la bayerita, e incluso, a edades más largas, la norstrandita aunque ello no excluye que la gibbsita pueda formarse a nivel de trazas. De nuevo este comportamiento parece estar relacionado con la solubilidad del aluminio a elevados pH. En trabajos previos (24, 25) se ha demostrado que en disoluciones sobresaturadas de aluminio a temperatura ambiente la secuencia de precipitación del hidróxido de aluminio es "amorfo-pseudoboehmite-bayerita". Es decir, la precipitación rápida de las disoluciones de aluminatos alcalinos produce bayerita.

Otro hecho importante a destacar es que si bien el aumento de la concentración de $\mathrm{NaOH}$ desde 2 hasta a $8 \mathrm{M}$ produce un incremento de las resistencias mecánicas (ver Tabla 3), también es verdad que con concentraciones en torno a $12 \mathrm{M}$, las resistencias ya no siguen aumentando; e incluso disminuyen. Las causas de este comportamiento no están claras, pudiendo deberse a diferentes hechos: i) un problema cinético relacionado con la menor velocidad de disolución del calcio al aumentar el $\mathrm{pH}$ de las disoluciones alcalinas: la muestra CAN12 presenta una alcalinidad extremadamente alta y, por tanto, la concentración de iones Ca en el medio debe ser baja (según la constante de solubilidad si la concentración de iones $\mathrm{OH}$ aumenta entonces la de Ca debe disminuir: $\left[\mathrm{Ca}^{2+}\right]\left[\mathrm{OH}^{-}\right]^{2}=10^{-4,5}$ (26)). De hecho, esta muestra, tras 2 días de hidratación no ha endurecido. Es decir, el $\mathrm{C}_{3} \mathrm{AH}_{6}$ se forma antes $-\mathrm{y}$ en mayor cantidad- en la muestra CAN8 que en la CAN12 y,
The amount of reacted calcium increased with curing time, forming $\mathrm{C}_{3} \mathrm{AH}_{6}$ (see Fig. 1(a), (b) and (c)) probably with increasing crystallinity. This would explain the sharp increase in 28-day alkali-hydrated cement bending and compressive strengths, with a value of $80 \mathrm{MPa}$ recorded for the latter in cement CAN8.

With respect to the reaction products, a number of authors $(16-19,21)$ have reported that the presence of low concentrations of alkalis in the mixing liquid accelerates the conversion of hexagonal to cubic hydrates. Due to the high alkalinity ( 8 and $12 \mathrm{M}$ ) of the solutions studied here, the metastable hexagonal aluminates converted to cubic species after only two days of hydration, whereas this process may take years in water-hydrated $C A C$.

Another of the main differences observed between water and alkaline solution hydration of CAC is the polymorphism found in $\mathrm{AH}_{3}$. In water (CAH), the $\mathrm{AH}_{3}$ crystallizes as gibbsite. In a mildly alkaline solution, such as used to hydrate CAN2, it also crystallizes as gibbsite or, in any event, as a mix of gibbsite and bayerite with a predominance of the former. In highly alkaline media, however, such as CAN8 and CAN12, bayerite, or at later ages norstrandite, prevails, although traces of gibbsite may also be observed. This would appear to be related to aluminium solubility at high $\mathrm{pH}$. Earlier studies $(24,25)$ showed that in supersaturated aluminium solutions, the sequence of aluminium hydroxide precipitation is "amorphous-pseudoboehmite-bayerite". In other words, rapid precipitation in alkaline aluminate solutions generates bayerite.

Another relevant finding was that while the increase in $\mathrm{NaOH}$ concentration from 2 to $8 \mathrm{M}$ prompted a rise in mechanical strength (Table 3), at concentrations of around $12 \mathrm{M}$ strength did not continue to grow, and in fact even declined. The reasons for this behaviour are not clear, but may be due to either of the following. i) The problem may be kinetic, related to the slower dissolution rate of calcium with rising $\mathrm{pH}$. The alkalinity of sample CAN12 was extremely high with, therefore, a low Ca ion concentration (according to the solubility constant principle, when $\mathrm{OH}$ ion concentration rises the Ca content must decline: $\left.\left[\mathrm{Ca}^{2+}\right]\left[\mathrm{OH}^{-}\right]^{2}=10^{-4.5},(26)\right)$. And in fact, this sample had not hardened after two days of hydration. In other words, $C_{3} A_{1} H_{6}$ formed earlier and in larger quantities in sample CAN8 than in CAN12, which would explain the higher 28-day strength in the former. The same situation was observed after 180 days, except 
por ello, a los 28 días, el desarrollo de resistencias es mayor en la primera. A los 180 días ocurre lo mismo, sólo que ahora la resistencia del CAN12 ha aumentado en más de $40 \mathrm{MPa}$. Podría darse la circunstancia de que a tiempos más largos, el cemento CAN12 desarrollara las mismas resistencias que se obtienen en el CAN8 (estudios a mayores edades están en ejecución actualmente); ii) la existencia de un valor óptimo de concentración de $\mathrm{NaOH}$ en torno a 8M, por debajo y por encima del cual el desarrollo mecánico resistente es menor. Ello implicaría que en condiciones de alcalinidad muy alta o muy baja la velocidad de condensación de los aluminatos cálcicos se vería reducida, para comprobar esta hipótesis serán necesarios más estudios al respecto.

En cuanto al comportamiento a los 180 días, las muestras siguen aumentando su resistencia a flexión y compresión, alcanzando valores a compresión incluso superiores a 100 MPa en el cemento CAN8. A esta edad se ha comprobado que las muestras han sufrido una carbonatación considerable. Esta carbonatación se ha producido simplemente por estar el material en contacto con la atmósfera en condiciones de elevada humedad. Lo cual pone de manifiesto lo señalado por otros autores, la presencia de álcalis en el medio acelera los procesos de carbonatación $(16,20,21)$.

Como consecuencia del proceso de carbonatación se forma principalmente calcita y vaterita, como se muestra en las Figuras 1, 2, 3, y 4 . Además se produce un descenso de la cantidad de $\mathrm{C}_{3} \mathrm{AH}_{6}$ y un aumento del $\mathrm{AH}_{3}$ (como bayerita, ver Figura 1), lo cual indica que se está produciendo la siguiente secuencia de reacciones (9): that in the interim CAN12 strength had grown by over 40 MPa. Cement CAN12 may in fact attain the same strength as CAN8 at later ages (longer term studies are presently underway). ii) There may be an optimal $\mathrm{NaOH}$ concentration of around 8M, below and above which mechanical strength development is smaller. This would imply that under conditions of very high or very low alkalinity, the rate of calcium aluminate condensation would decline. Further study would be required to verify this hypothesis.

The 180-day samples showed that bending and compressive strength continued to grow up to that age, to values of over $100 \mathrm{MPa}$ in cement CAN8. The substantial carbonation observed in these older samples was due to their mere contact with very humid air, which is consistent with the reports of other authors $(16,20,21)$ to the effect that the presence of alkalis in the medium accelerates carbonation.

Carbonation led to the formation, primarily, of calcite and vaterite, as shown in Figures 1, 2, 3 and 4. Moreover, $\mathrm{C}_{3} \mathrm{AH}_{6}$ was observed to decline and $\mathrm{AH}_{3}$ (as bayerite, see Figure 1) to rise, indicating that the following sequence of reactions was taking place (9):

$$
\begin{gathered}
\mathrm{C}_{3} \mathrm{AH}_{6}+\mathrm{CO}_{2} \rightarrow \mathrm{C}_{3} \mathrm{AH}_{4}\left(\mathrm{CO}_{2}\right)+2 \mathrm{H} \\
\mathrm{C}_{3} \mathrm{AH}_{4}\left(\mathrm{CO}_{2}\right)+\mathrm{CO}_{2} \rightarrow \mathrm{C}_{3} \mathrm{AH}_{2}\left(\mathrm{CO}_{2}\right)_{2}+2 \mathrm{H} \\
\mathrm{C}_{3} \mathrm{AH}_{2}\left(\mathrm{CO}_{2}\right)_{2} * \mathrm{CO}_{2} \rightarrow \mathrm{C}_{3} \mathrm{~A}\left(\mathrm{CO}_{2}\right)_{3}+2 \mathrm{H}
\end{gathered}
$$

Siendo este último "compuesto" $\left[\mathrm{C}_{3} \mathrm{~A}\left(\mathrm{CO}_{2}\right)_{3}\right]$ idéntico a: $\mathrm{Al}_{2} \mathrm{O}_{3}+\mathrm{CaCO}_{3}$

Así, las muestras más alcalinas son las que presentan un mayor contenido en calcita (CAN8 y CAN12), mientras que la CAN2 presenta una mayor proporción de vaterita. Este hecho de nuevo está relacionado con la disminución de la velocidad de disolución del calcio conforme aumenta el pH. Según S.R. Dickinson et al. (27), la calcita es el carbonato cálcico termodinámicamente más estable, mientras que la vaterita es el más inestable. La formación de estos carbonatos depende de la concentración de $\mathrm{Ca}^{2+}$ en disolución y de la presión parcial del $\mathrm{CO}_{2}$. Cuando hay poco $\mathrm{Ca}^{2+}$ en disolución, el sistema está termodinámicamente controlado, formándose calcita. Sin embargo a altas $\left[\mathrm{Ca}^{2+}\right]$ es la cinética la que controla la evolución composicional del sistema y se forma vaterita. Por tanto, es de suponer que en el cemento CAN2 habrá más $\mathrm{Ca}^{2+}$ en disolución que en las CAN8 y CAN12.
The last "compound" $\left[\mathrm{C}_{3} \mathrm{~A}\left(\mathrm{CO}_{2}\right)_{3}\right]$ was identical to $\mathrm{Al}_{2} \mathrm{O}_{3}$ $+\mathrm{CaCO}_{3}$.

The higher proportion of calcite in the two more highly alkaline samples (CAN8 and CAN12) and the prevalence of vaterite in CAN2 were also related to the decline in the rate of calcium dissolution with rising $\mathrm{pH}$. According to S.R. Dickinson et al. (27), calcite is the most and vaterite the least thermodynamically stable calcium carbonate. The formation of these carbonates depends on the $\mathrm{Ca}^{2+}$ concentration in the solution and the partial pressure exerted by the $\mathrm{CO}_{2}$. When the $\mathrm{Ca}^{2+}$ concentration is low, the system is thermodynamically controlled, and calcite forms. At high $\left[\mathrm{Ca}^{2+}\right]$, however, system composition is governed by kinetics, resulting in vaterite formation. Therefore, CAN2 presumably contained more dissolved $\mathrm{Ca}^{2+}$ than CAN8 or CAN12. 
Además, también es de reseñar la aparición de un carboaluminato cálcico hidratado a los 180 días de edad: el $\mathrm{C}_{4} \mathrm{AcH}_{11}$. Este carboaluminato aparece con especial intensidad en la CAN2 y, un poco menos, en la muestra CAN8. Estos carboaluminatos son compuestos metaestables, especies intermedias del proceso de carbonatacion $(9,19,21,28)$.

Por otra parte, el descenso de la cantidad de $\mathrm{C}_{3} \mathrm{AH}_{6}$ en los materiales de 180 días no va acompañado de un descenso en las resistencias mecánicas, sino al contrario. Las elevadas resistencias obtenidas a 180 días se ha observado que en general se corresponden con un incremento en la cantidad de carbonatos y de bayerita. Así, la muestra CAN8, que presenta una mayor proporción de hidratos cúbicos, da lugar a una mayor cantidad de carbonatos y a mayores valores de resistencia mecánica. En este caso los procesos de carbonatación podrían ser considerados como coadyuvantes del desarrollo mecánico, no obstante para corroborar este hecho, así como otros anteriormente expuestos, están en curso estudios de más larga duración.

\section{CONCLUSIONES}

Las principales conclusiones que pueden extraerse del presente trabajo son:

- Al hidratar alcalinamente el cemento de aluminato de calcio, en medios fuertemente concentrados, se modifica la naturaleza de los productos de reacción formados y consecuentemente el comportamiento mecánico en lo que respecta a la hidratación normal de CAC con agua.

- La presencia de elevados contenidos de álcalis retrasa los procesos de rápido endurecimiento de CAC con agua. No obstante a edades superiores (28 días), las resistencias mecánicas del CAC hidratado alcalinamente aumentan conforme aumenta la alcalinidad de la disolución activadora, hasta llegar a un valor óptimo de concentración en torno a $\mathrm{NaOH} 8 \mathrm{M}$, a partir del cual, las resistencias disminuyen.

- En las muestras de CAC hidratado con las disoluciónes de $\mathrm{NaOH}$, en vez de los aluminatos hexagonales que se forman normalmente en la hidratación con agua $\left(\mathrm{CAH}_{10}\right.$ y $\left.\mathrm{C}_{2} \mathrm{AH}_{8}\right)$ se forman $\mathrm{C}_{3} \mathrm{AH}_{6}$ y $\mathrm{AH}_{3}$. La forma polimórfica del $\mathrm{AH}_{3}$ depende de la alcalinidad del medio: gibbsita al hidratar el CAC y con $\mathrm{NaOH} 2 \mathrm{M}$; bayerita al hidratarlo con disoluciones de mayor alcalinidad CAN8 y CAN12.

\section{AGRADECIMENTOS}

Los autores de este trabajo quieren dar las gracias a la Dirección General de Investigaciones Científicas, por la financiación del proyecto BIA2004-04835. C. Pastor
The hydrated calcium carboaluminate $\mathrm{C}_{4} \mathrm{AcH}_{11}$ also appeared after 180 days. The presence of this carboaluminate was particularly intense in CAN2 and somewhat less so in CAN8. These compounds are metastable, intermediate species in the carbonation process $(9,19$, $21,28)$.

Moreover, the decline in the $\mathrm{C}_{3} \mathrm{AH}_{6}$ content in the 180 day material did not concur with a decline in mechanical strength, but rather the contrary. The high 180-day strength values obtained were found to go hand-in-hand with increases in carbonate and bayerite content. Consequently, the CAN8 sample, which exhibited the highest proportion of cubic hydrates, also had the highest carbonate content and mechanical strength. In this case the carbonation processes might be thought to contribute to strength development. Nonetheless, longer term studies are underway to corroborate this and other the presumptions set out above.

\section{CONCLUSIONS}

The main conclusions that can be drawn from the present study are:

- The alkali hydration of calcium aluminate cement in highly concentrated media changes the nature of the reaction products formed under standard water hydration, and consequently the respective mechanical strength.

- High alkali content retards the rapid hardening that takes place when CAC is hydrated with water. Nonetheless, at later ages (28 days), the mechanical strength of alkali-hydrated CAC increases with the alkalinity of the activating solution up to an optimal $\mathrm{NaOH}$ concentration of around 8M; at higher values, strength declines.

- In NaOH-hydrated CAC samples, the aluminates formed are $\mathrm{C}_{3} \mathrm{AH}_{6}$ and $\mathrm{AH}_{3}$, instead of the hexagonal aluminates $\left(\mathrm{CAH}_{10}\right.$ and $\left.\mathrm{C}_{2} \mathrm{AH}_{8}\right)$ appearing in standard water hydration. The $\mathrm{AH}_{3}$ polymorph formed depends on the alkalinity of the medium: gibbsite when $\mathrm{CAC}$ is hydrated with $2 \mathrm{M} \mathrm{NaOH}$ and bayerite when the higher alkalinity solutions, CAN8 and CAN12, are used.

\section{ACKNOWLEDGEMENTS}

This study was funded by the Spanish Directorate General of Scientific Research under project BIA2004-04835.

C. Pastor participated thanks to a university professor 
agradece al Ministerio de Educación y Ciencia por la concesión de la beca FPU. A. Fernández-Jiménez también agradece al CSIC la financiación del contrato I3P ((REF. 13P-PC2004L) cofinanciado por el Fondo Social Europeo. training internship granted by the Ministry of Education and Science. A. Fernández-Jiménez is the beneficiary of an integrated employability pathway contract with the Spanish National Research Council, co-funded by the European Social Fund.

\section{BIBLIOGRAFÍA / BIBLIOGRAPHY}

(1) Gartner, E.: "Industrially interesting approaches to 'low- $\mathrm{CO}_{2}$ ' cements". Cem. Conr. Res. 34 (2004),

pp. 1489-1498. doi:10.1016/j.cemconres.2004.01.021

(2) Metha, P. K: "Concrete: structure, properties and materials". Prentice-Hall,mlnc. Englewood Cliffs, New York (1986).

(3) Palomo, A.; Grutzeck, M. W.; Blanco, M. T.: "Alkali activated fly ashes. A cement for the future". Cem. Con. Res. 29 (1999), pp. 1323-1329. doi:10.1016/S0008-8846(98)00243-9

(4) Fernández-Jiménez, A.; Palomo, A.: "Characterisation of fly ashes. Potential reactivity as alkaline cements". Fuel 82 (2003), pp. 22592265. doi:10.1016/S0016-2361(03)00194-7

(5) Fernández-Jiménez, A.; Palomo, A.: "Composition and microstructure of alkali activated fly ash binder: Effect of the activator". Cem. Conr. Res. 35 (2005), pp. 1984-1992. doi:10.1016/j.cemconres.2005.03.003

(6) Fernández-Jiménez, A.; Palomo, A., Sobrados I., Sanz J.: "The role played by the reactive alumina content in the alkaline activation of fly ashes". Microporous and Mesoporous Materials 91 (2006), pp. 111-119. doi:10.1016/j.micromeso.2005.11.015.

(7) Duxson, P.; Fernández-Jiménez, A.; Provis, J. L.; Lukey, G. C.; Palomo, A.; van Deventer, J. S. J.: "Geopolymer technologt: the current state of the art". J. Mater. Sci. 42 (2007), pp. 2917-2933. doi: 10.1007/s10853-006-0637-Z

(8) Kovalchuk, G.; Fernández-Jiménez, A.; Palomo, A.: "Alkali-activated fly ash. Relation ship between mecahanical strength gains and initial ash chemistry (Part I)". Mater. Construcc. 50 (2008), pp. 35-52.

(9) Vázquez, T.; Triviño, F.; Ruiz de Gauna, A.: "Estudio de las transformaciones del cemento aluminoso hidratado. Influencia del anhídrido carbónico, temperatura, humedad y adición de caliza en polvo". Monogr. Inst. Eduardo Torroja, Constr. Cem. 334 (1976), p. 47.

(10) George, C. M.: "Industrial aluminous cement". Structure and Performance of Cements. Ed. P. Barnes (1983).

(11) Pérez, M.; Vázquez, T.; Triviño, F.: "Study of stabilized phases in high alumina cement mortars". Cem. Concr. Res. 13 (1983), pp. 759-770. doi:10.1016/0008-8846(83)90077-7

(12) Tarte, P. "Infra-red spectra of inorganic aluminates and characteristic vibrational frequencies of AlO4, tetrahedra and AlO6 octahedra". Spectrochimica Acta, vol. 23a (1967), pp. 2127- 2143.

(13) Capmas, A.; Sorrentino, D.; Damidot, D.: "Effect of temperature on setting time of calcium aluminate cements". Calcium Aluminate Cements. Ed. R.J. Mangabhai (1990).

(14) Barret, P.; Bertrandie, D.: "Hydration of aluminate cements". Advances in cement and Concrete. Ed. M.W. Grutzeck and S.L. Sarkar (1994).

(15) Garcés, P.; Alcocel, E. G.; Chincón, S.; Andreu, C. G.; Alcaide, J.: "Efect of curing temperature in some hydration characteristics of calcium aluminate cement compared with those of Portland cement". Cem. Concr. Res. 27 (1997), pp. 1343-1355. doi:10.1016/S00088846(97)00136-1

(16) Fernández-Carrasco, L.; Puertas, F.; Blanco-Varela, M. T.; Vázquez, T. "Nuevos avances en la carbonatación del cemento aluminoso, 'Hidrólisis alcalina'". Mater. Construcc. 149 (253) (1999), pp. 47-55.

(17) Fernández-Carrasco, L.; Puertas, F.; Blanco-Valera, M. T.; Vázquez, T.; Rius. J.: "Síntesis and crystal structure solution of potassium dawsonite: An intermediate compound in the alkaline hydrolysis of calcium aluminate cements". Cem. Concr. Res. 32 (2005), pp. 641-646. doi:10.1016/j.cemconres.2004.04.018

(18) Blanco Varela, M. T.; Martínez-Ramírez, S.; Vázquez, T.; Sánchez-Moral, S.: "Role of alkalis of aggregate origin in the deterioration of CAC concrete". Cem. Concr. Res. 35 (2005), pp. 1698-1704. doi:10.1016/j.cemconres.2004.08.015

(19) García Alcocel, E.; Garcés, P.; Chinchón, S.: "General study of alkaline hydrolysis in calcium aluminate cement mortars under a broad range of experimental conditions". Cem. Concr. Res. 30 (2000), pp. 1689-1699. doi:10.1016/S0008-8846(00)00396-3

(20) Fernández-Carrasco, L.: "Procesos de hidratación y carbonatación del cemento de aluminato de calcio; influencia de los álcalis. Alteraciones microestructurales y relación con sus propiedades mecánicas". Tesis Doctoral, UAM, Facultad de Ciencias (2000).

(21) Puertas, F.; Fernández-Carrasco, L.; Blanco-Valera, M. T.; Vázquez, T.; de la Fuente, A.: "Influence of KOH solution on the hydration or carbonation of high alumina cement mortars" J. Materials Sci 31 (1996), pp. 2819-2827. doi:10.1007/BF00355988

(22) Fernández-Carrasco, L.; Puertas, F.; Blanco-Varela, M. T.; Vázquez, T.: "Carbonation of calcium aluminate cement pastes". Mater Construcc. 51, Nos 263-264 (2001), pp. 127-136.

(23) Mikuni, A.; Komatsu, R.; Ikeda, K.: "Dissolution properties of some fly ash fillers applying to geopolymeric materials in alkali solution". J. Mater Sci 42 (2007), pp. 2953-2957. doi:10.1007/s10853-006-0530-9 
(24) van Straten, H. A.; Holtkamp, B. T. W.; de Bruyn, P. L.: "Precipitation from supersaturated aluminate solutions: I. Nucleation and growth of solid phases at room temperature". J. Colloid Interface Sci. 98 (1984), pp. 342-362.

(25) van Straten, H. A.; de Bruyn, P. L.: "Precipitation from supersaturated aluminate solutions". J. Colloid Interface Sci. 102 (1984), pp. 260-277. doi:10.1016/0021-9797(84)90218-2

(26) Dron, R.; Brivot, F.: "Thermodynamic and kinetic approach to the alkali-silica reaction. Part 1: concepts". Cem. Concr. Res. 22 (1992), pp. 941-948. doi:10.1016/0008-8846(92)90118-F

(27) Dickinson, S. R.; Henderson, G.E.; McGrath, K. M.: "Controlling the kinetic versus thermodynamic crystallisation of calcium carbonate". Journal of Crystal Growth 244 (2002), pp. 369-378. doi:10.1016/S0022-0248(02)01700-1

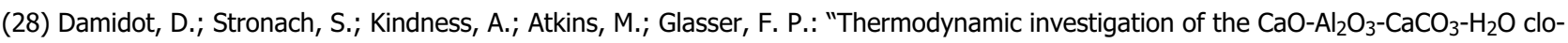
sed system at $25^{\circ} \mathrm{C}$ and the influence of $\mathrm{Na}_{2} \mathrm{O}^{\prime \prime}$. Cem. Concr. Res. 24 (1994), pp. 563-572 doi:10.1016/0008-8846(94)90145-7 